\title{
DESKRIPSI SEKOLAH DASAR DI KABUPATEN MINAHASA TENGGARA BERDASARKAN STANDAR ISI, STANDAR PENDIDIK DAN TENAGA KEPENDIDIKAN, STANDAR SARANA DAN PRASARANA DAN STANDAR PENGELOLAAN
}

\author{
Leivy G. Paruntu ${ }^{1)}$, Djoni Hatidja ${ }^{1)}$, Nelson Nainggolan ${ }^{1)}$ \\ 1)Program Studi Matematika, FMIPA, Universitas Sam Ratulangi Manado \\ e-mail : gabriella.paruntu@gmail.com; dhatidja@gmail.com; n-nelson@unsrat.ac.id
}

\begin{abstract}
ABSTRAK
Standar Nasional Pendidikan merupakan sistem pendidikan yang diterapkan di seluruh wilayah hukum Negara Kesatuan Republik Indonesia. Penelitian ini bertujuan untuk Mendeskripsikan Sekolah Dasar di Kabupaten Minahasa Tenggara berdasarkan 4 Standar Nasional Pendidikan. Sampel yang diambil adalah 30 Sekolah Dasar di Kabupaten Minahasa Tenggara. Pengambilan sampel menggunakan Purposive Random Sampling kecamatan dan Simple Random Sampling untuk menentukan sekolah-sekolah yang dijadikan sampel. Penelitian dilakukan pada bulan September 2017. Metode yang digunakan adalah dengan analisis deskripsi. Sebagian besar sekolah yang terakreditasi A sudah cukup baik dalam keempat standar yang diteliti dan memenuhi setiap standar yang ditetapkan. Namun ada $11,11 \%$ sekolah yang terakreditasi A masih kurang baik dalam beberapa standar. Pada keempat standar yang diteliti, rata-rata nilai tertinggi dimiliki oleh sekolah-sekolah yang terakreditasi A seperti SD GMIM Ratahan untuk standar isi dan standar pengelolaan, SD Negeri 2 Liwutung dan SD Negeri 1 Tombatu untuk standar pendidik dan tenaga kependidikan, sedangkan nilai tertinggi untuk standar sarana dan prasarana dimiliki oleh SD GMIM Bunag yang sekolahnya belum terakreditasi. Untuk nilai terendah pada standar pendidik dan tenaga kependidikan, standar sarana dan prasarana, dan standar pengelolaan dimiliki oleh sekolah-sekolah yang belum terakreditasi yaitu SD Negeri Kecil Banga, SD GMIM 1 Silian, dan SD GMIM Lobu. Sedangkan nilai terendah pada standar isi dimiliki oleh SD Negeri 1 Liwutung yang merupakan salah satu sekolah yang sudah terkreditasi A.
\end{abstract}

Kata kunci : Sekolah Dasar, Analisis Deskripsi, Kabupaten Minahasa Tenggara

\section{DESCRIPTION OF ELEMENTARY SCHOOL IN SOUTHEAST MINAHASA REGENCY BASED ON CONTENT STANDARDS, STANDARD OF EDUCTORS AND EDUCATION PERSONNEL, STANDARDS OF FACILITIES AND INFRASRUCTURE, AND MANAGEMENT STANDARDS}

\begin{abstract}
National Education Standards is an education system implemented throughout the jurisdiction of the Unitary State of the Republic of Indonesia. This study aims to describe elementary school in Southeast Minahasa Regency based on 4 National Education Standards. Samples taken were 30 elementary school in Southeast Minahasa Regency. Sampling using Purposive Random Sampling to determine the sub-district and Simple Random Sampling to determine the school that were sampled. The study was conducted in September 2017. The method used is by the description analysis. Most of the A-accredited school are good enough in all four standards studied and meets any specified standards. But there are 11,11\% of schools accredited A is still not good in some standards. In the four standards studied, the highest average score in owned by A-accredited school such as GMIM Ratahan Elementary School for standards contents and management standards, Public Elementary School 2 Liwutung and Public Elementary School 1 Tombatu for the standard of educators and education personnel, while the highest value for the standard facilities and infrastructure is owned by GMIM Bunag Elementary School which has not been accredited. For the lowest score on the standards of eductors and education personnel, the standard of facilities and infrastructure, and management standards are owned by school that have
\end{abstract}


not been acctredited namely Public Elementary School Kecil Banga, GMIM 1 Silian Elementary School, and GMIM Lobu Elementary School. While the lowest score on the content standard is owned by Public Elementary School 1 Liwutung which is one of the schools thet have been accredited A.

Keywords : Elementary School, Description Analysis, Southeast Minahasa Regency

\section{PENDAHULUAN}

Undang-Undang Republik Indonesia nomor 20 tahun 2003 tentang sistem pendidikan nasional menyatakan bahwa sistem pendidikan nasional harus mampu menjamin pemerataan kesempatan pendidikan, peningkatan mutu serta relevansi dan efisiensi manajemen pendidikan untuk menghadapi tantangan sesuai dengan tuntutan perubahan kehidupan lokal, nasional, dan global sehingga perlu dilakukan pembaharuan pendidikan secara terencana, terarah, dan berkesinambungan.

Pendidikan nasional berfungsi untuk mengembangkan kemampuan dan membentuk watak serta peradaban bangsa yang bermartabat dalam rangka mencerdaskan kehidupan bangsa. Sedangkan tujuan pendidikan nasional adalah untuk mengembangkan potensi peserta didik agar menjadi manusia yang beriman dan bertakwa kepada Tuhan Yang Maha Esa, berakhlak mulia, sehat, berilmu, cakap, kreatif, mandiri, dan menjadi warga negara yang demokratis serta bertanggung jawab (Undang-undang nomor 20 tahun 2003 pasal 3).

Penerapan tujuan pendidikan nasional tersebut diawali pada pendidikan dasar yang terdiri dari Sekolah Dasar (SD) dan pendidikan menengah yaitu: Sekolah Mengengah Pertama (SMP) dan Sekolah Menengah Atas Kejuruan (SMA/SMK). Kenyataan yang terjadi saat ini adalah adanya perbedaan yang cukup besar antara mutu pendidikan di kota-kota besar dengan di daerah-daerah baik pada pendidikan dasar maupun pendidikan menengah.

Untuk mengurangi perbedaan mutu pendidikan tersebut, maka telah dibuatkan Peraturan Pemerintah (PP) nomor 19 tahun 2005 tentang Standar Nasional Pendidikan. Standar nasional pendidikan terdiri dari 8 standar, yaitu Standar Kompetensi Lulusan, Standar Isi, Standar Proses, Standar Pendidikan dan Tenaga Kependidikan, Standar Sarana dan Prasarana, Standar
Pengelolaan, Standar Pembiayaan Pendidikan dan Standar Penilaian Pendidikan.

Sejak tahun anggaran 2009, pemerintah telah menerapkan 20\% APBN untuk sektor pendidikan sesuai amanat dari Undang-Undang Dasar 1945. Anggaran yang besar ini diharapkan secara bertahap dapat meningkatkan mutu pendidikan dasar dan menengah sehingga bisa mencapai standar nasional pendidikan.

Sebelum anggaran disalurkan maka pemerintah yaitu Kementrian Pendidikan dan Kebudayaan (KEMDIKBUD) harus mempunyai database yang akurat mengenai mutu pendidikan dari setiap sekolah yang ada di Kabupaten/Kota seluruh Indonesia. Diharapkan dengan database yang akurat, maka bantuan pendidikan dapat tepat sasaran dan tepat penggunaannya.

Hatidja (2010), telah melakukan penelitian mengenai mutu pendidikan Sekolah Menengah Atas (SMA) di Kota Manado dengan menggunakan analisis Biplot. Pada penelitian ini tidak menggunakan delapan 8 (delapan) standar nasional pendidikan namun hanya menggunakan beberapa komponen dari 3 (tiga) standar nasional pendidikan, yaitu standar konmpetensi lulusan, standar sarana dan prasarana serta standar proses. Hasil penelitian ini dapat memetakkan kelebihan dan kekurangan SMA-SMA di Kota Manado berdasarkan 3 standar tersebut. Kemudian Taogan, Paendong dan Mongi (2016) juga melakukan penelitian yang sama di Kabupaten Minahasa Selatan dengan menggunakan 4 (empat) standar nasional pendidikan, yaitu standar isi, standar pendidik dan tenaga kependidikan, standar kompetensi lulusan, dan standar penilaian pendidikan.

Kabupaten Minahasa Tenggara yang diresmikan pada tanggal 23 Mei 2007 oleh Menteri Dalam Negeri adalah Kabupaten baru di Provinsi Sulawesi Utara, hasil pemekaran dari Kabupaten Minahasa Selatan. Kabupaten ini memiliki 42 ekolah TK, 97 SD dan 19 SMP dan 15 SMA/SMK. Pada usinya yang masih muda dapat dipastikan bahwa, 
Kabupaten Minahasa Tenggara belum memiliki database yang akurat mengenai mutu pendidikan dari sekolah-sekolah khususnya Sekolah Dasar (SD). Berdasarkan standar kompetensi lulusan, standar isi dan standar proses, SMP SMP di Kabupaten Minahasa Tenggara dapat dikategorikan: $46 \%$ SMP memiliki mutu baik, dan 54\% SMP memiliki mutu yang tidak baik (Hatidja dan Take, 2012). Namun berdasarkan standar pendidikan dan tenaga kependidikan, standar sarana dan prasarana, standar pengelolaan dan standar pembiayaan pendidikan, SMP SMP di Kabupaten Minahasa Tenggara dapat dikategorikan: $77 \%$ memiliki mutu baik, dan 23\% memiliki mutu yang tidak baik (Daman dan Hatidja, 2012). Kedua hasil di atas dilakukan dengan menggunakan Analisis Biplot.

Purwanto, Hatidja dan Paendong (2015); Sepang, Hatidja dan Langi (2015), menyatakan bahwa terdapat 2 SMA dan 2 SMK di Kabupaten MITRA mempunyai mutu yang tidak memenuhi Standar Nasional Pendidikan (SNP). Peubah yang digunakan adalah 8 SNP (Standar Kompetensi Lulusan, Standar Isi, Standar Proses, Standar Tenaga Pendidik dan Tenaga Kependidikan, Standar Sarana dan Prasarana, Standar Pengelolaan, Standar Pembiayaan Pendidikan dan Standar Penilaian Pendidikan)

Rembang, Hatidja dan Komaling (2017); Tarega, Hatidja, dan Paendong (2017) melakukan penelitian yang sama, namun peubah yang digunakan diukur berrdasarkan Evaluasi Diri Sekolah.

Untuk mengetahui apakah pendidikan dasar di kabupaten Minahasa Tenggara sudah memenuhi standar nasional pendidikan, maka tentu harus dilakukan kajian yang mendalam mengenai Sekolah Dasar.

Berdasarkan latar belakang tersebut, maka perlu dilakukan penelitian mengenai mutu sekolah-sekolah khususnya SD di Kabupaten Minahasa Tenggara apakah sudah memenuhi standar nasional pendidikan ataukah belum. Dengan penelitian ini, diharapkan Kabupaten Minahasa Tenggara memiliki database yang akurat mengenai mutu SD sehingga bantuan yang akan disalurkan melalui pemerintah maupun swasta dapat tepat sasaran dan tepat guna.

\section{TINJAUAN PUSTAKA}

\section{Minahasa Tenggara}

Kabupaten Minahasa Tenggara adalah kabupaten baru di Provinsi Sulawesi Utara, Indonesia, dengan ibu kota: Ratahan yang merupakan pemekaran dari Kabupaten Minahasa Selatan. Kabupaten ini diresmikan pada tanggal 23 Mei 2007 oleh Menteri Dalam Negeri Ad Interim Widodo AS bersama dengan tiga kabupaten lainnya, yaitu Kabupaten Bolaang Mongondow Utara, Kota Kotamobagu, dan Kabupaten Kepulauan Siau Tagulandang Biaro (Sitaro) (Agust. J, 2016)

Infrastruktur yang dimiliki, yaitu: 1) lembaga keuangan yang terdiri dari Bank BRI dan BPR dan koperasi; 2) sarana pendidikan yang terdiri dari $42 \mathrm{TK}, 97 \mathrm{SD}$, 19 SMP, 9 SMA, 6 SMK dan 1 MAS; 3) fasilitas kesehatan yang terdiri dari puskesmas, puskesmas pembantu, dan klinik $\mathrm{KB}$, dan tenaga paramedis yang memadai; 4) fasilitas telekomunikasi yang terdiri dari sambungan telepon, wartel, telepon, jaringan TV dan radio; serta 5) beberapa fasilitas olahraga.

\section{Standar Nasional Pendidikan}

Standar Nasional Pendidikan adalah kriteria minimal tentang sistem pendidikan di seluruh wilayah hukum Negara Kesatuan Republik Indonesia (PP Nomor 19 tahun 2005 pasal 1).

Standar Nasional Pendidikan terdiri dari: 1) Standar Kompetensi Lulusan; 2) Standar Isi; 3) Standar Proses; 4) Standar Pendidik dan Tenaga Kependidikan; 5) Standar Sarana dan Prasarana; 6) Standar Pengelolaan; 7) Standar Pembiayaan Pendidikan; dan 8) Standar Penilaian Pendidikan (PP Nomor 19 tahun 2005 pasal 2). Standar Nasional Pendidikan berfungsi sebagai dasar dalam perencanaan, pelaksanaan, pengawasan pendidikan dalam rangka mewujudkan pendidikan nasional yang bermutu. Sedangkan tujuan Standar Nasional Pendidikan adalah menjamin mutu pendidikan nasional dalam rangka mencerdaskan kehidupan bangsa dan membentuk watak serta peradaban bangsa yang bermartabat. Standar Nasional Pendidikan disempurnakan secara terencana, terarah, dan berkelanjutan sesuai dengan tuntutan perubahan kehidupan lokal, nasional, 
dan global (PP Nomor 19 tahun 2005 pasal 34).

\section{Analisi Deskripsi}

Beberapa ahli mengatakan bahwa analisis multivariat adalah hubungan antara atau diantara lebih dari dua variabel atau peubah. Tujuan analisis multivariat adalah mengukur, menerangkan dan memprediksi tingkat relasi di antara variat-variat. Jadi, karakter multivariat tidak sekedar berada pada jumlah variabel atau observasi yang dilibatkan dalam analisis tetapi juga pada kombinasi antar variat. (Simamora, 2005).

Analisis multivariat lebih banyak menekankan pada metode-metode statistik yang bersifat menggambarkan dan menganalisis data-data multivariat. Cara penggambaran data tersebut sebagian besar disajikan dalam bentuk gambar atau grafik. Dengan demikian analisis multivariat sebenarnya merupakan bagian dari statistika deskripsi (Johnson and Wichern, 2005).

\section{METODOLOGI PENELITIAN}

\section{Waktu dan Tempat}

Penelitian ini dilakukan pada bulan September 2017 dan tempat penelitian dilakukan di Kabupaten Minahasa Tenggara.

\section{Sumber Data}

Data yang akan digunakan dalam penelitian ini berasal dari data primer yang diambil pada SD di Kabupaten Minahasa Tenggara yang berisi Standar Nasional Pendidikan. Data-data dikumpul melalui kuisioner di setiap sekolah berdasarkan wawancara yang dilakukan terhadap Guru dan Kepala Sekolah.

\section{Objek Penelitian}

Objek penelitian yaitu $30 \mathrm{SD}$ di Kabupaten Minahasa Tenggara dapat dilihat pada Tabel 1.

Penelitian ini menggunakan data hasil survei dengan menggunakan 2 teknik pengambilan sampel yakni Purposive Random Sampling atau pengambilan sampel secara sengaja yang digunakan untuk menentukan jumlah sekolah di setiap kecamatan yang akan dijadikan sampel dan Simple Random Sampling atau pengambilan sampel secara acak yang digunakan untuk menentukan sekolah-sekolah yang dijadikan sampel.

Tabel 1. Nama-nama SD yang menjadi objek penelitian

\begin{tabular}{|c|l|c|}
\hline No & \multicolumn{1}{|c|}{ Nama Sekolah } & Simbol \\
\hline $\mathbf{1}$ & SD N 2 RATAHAN & K1 \\
\hline $\mathbf{2}$ & SD N WIOI & K2 \\
\hline $\mathbf{3}$ & SD GMIM RATAHAN & K3 \\
\hline $\mathbf{4}$ & SD INPRES TOSURAYA & K4 \\
\hline $\mathbf{5}$ & SD GMIM RASI & K5 \\
\hline $\mathbf{6}$ & SD N 1 LIWUTUNG & K6 \\
\hline $\mathbf{7}$ & SD N 2 LIWUTUNG & K7 \\
\hline $\mathbf{8}$ & SD N 3 LIWUTUNG & K8 \\
\hline $\mathbf{9}$ & SD INPRES PANGU & K9 \\
\hline $\mathbf{1 0}$ & SD INPRES LIWUTUNG & K10 \\
\hline $\mathbf{1 1}$ & SD N 1 MOLOMPAR & K11 \\
\hline $\mathbf{1 2}$ & SD N MUNDUNG & K12 \\
\hline $\mathbf{1 3}$ & SD GMIM KUYANGA & K13 \\
\hline $\mathbf{1 4}$ & SD NEGERI 2 TOMBATU & K14 \\
\hline $\mathbf{1 5}$ & SD GP KALI & K15 \\
\hline $\mathbf{1 6}$ & SD GMIM LOBU & K16 \\
\hline $\mathbf{1 7}$ & SD N KECIL BANGA & K17 \\
\hline $\mathbf{1 8}$ & SD GMIM BUNAG & K18 \\
\hline $\mathbf{1 9}$ & SD NEGERI MAULIT & K19 \\
\hline $\mathbf{2 0}$ & SD N INPRES MOLOMPAR & K20 \\
\hline $\mathbf{2 1}$ & SD GMIM WATULINEY & K21 \\
\hline $\mathbf{2 2}$ & SD NEGERI TABABO & K22 \\
\hline $\mathbf{2 3}$ & SD N 1 BELANG & K23 \\
\hline $\mathbf{2 4}$ & SD NEGERI 1 TOMBATU & K24 \\
\hline $\mathbf{2 5}$ & SD GMIM RANOKETANG & K25 \\
\hline $\mathbf{2 6}$ & SD N 1 TOUMDANOW & K26 \\
\hline $\mathbf{2 7}$ & SD GMIM 1 SILIAN & K27 \\
\hline $\mathbf{2 8}$ & SD NEGERI SILIAN RAYA & K28 \\
\hline $\mathbf{2 9}$ & SD INPRES KALI & K29 \\
\hline $\mathbf{3 0}$ & SD GMIM TAMBELNG & K30 \\
\hline & & \\
\hline
\end{tabular}

Besarnya sampel ditentukan dengan rumus sebagai berikut:

$$
n=\frac{N}{N \cdot d^{2}+1}
$$

Dimana: $n=$ jumlah sampel

$N=$ jumlah populasi

$d^{2}=$ presisi yang ditetapkan $(10 \%)$

(Ridwan dan Akdon, 2005)

Berdasarkan persamaan diatas, diketahui :

$$
\begin{aligned}
& \mathrm{N}=97 \\
& d^{2}=0,1
\end{aligned}
$$

maka : $n=\frac{97}{97 \cdot 0,1+1}$

$$
n=\frac{97}{10,7}=9,0654
$$


Sehinggah diperoleh besar sampel minimum yang harus diambil adalah 10, namun di ambil 30 sampel agar penelitian yang dialakukan mendapat hasil yang lebih akurat.

\section{Peubah Penelitian}

Peubah-peubah yang diamati adalah peubah standar nasional pendidikan yang terdiri dari Standar Isi, Standar Pendidik dan Tenaga Kependidikan, Standar Sarana dan Prasarana, dan Standar Pengelolaan. Peubahpeubah yang diamati disajikan pada Tabel 25 .

Tabel 2. Peubah Standar Isi (X1)

\begin{tabular}{|c|l|}
\hline Kode & \multicolumn{1}{|c|}{ Nama Peubah } \\
\hline $\mathrm{X} 11$ & Kurikulum yang digunakan \\
\hline $\mathrm{X} 12$ & $\begin{array}{l}\text { Jenis penilaian yang diterapkan } \\
\text { dalam kurikulum }\end{array}$ \\
\hline
\end{tabular}

Tabel 3. Peubah Standar Pendidik dan Tenaga Kependidikan (X2)

\begin{tabular}{|c|l|}
\hline Kode & \multicolumn{1}{|c|}{ Nama Peubah } \\
\hline X21 & $\begin{array}{l}\text { Jumlah dan kualifikasi masing- } \\
\text { masing guru: }\end{array}$ \\
\hline X22 & Kualifikasi kepala sekolah \\
\hline X23 & $\begin{array}{l}\text { Jumlah dan kualifikasi tenaga } \\
\text { administrasi: }\end{array}$ \\
\hline X24 & $\begin{array}{l}\text { Jumlah dan kualifikasi tenaga } \\
\text { perpustakaan }\end{array}$ \\
\hline X25 & $\begin{array}{l}\text { Jumlah dan kualifikasi tenaga } \\
\text { kebersihan }\end{array}$ \\
\hline
\end{tabular}

Tabel 4. Peubah Standar Sarana dan Prasarana (X3)

\begin{tabular}{|c|l|}
\hline Kode & \multicolumn{1}{|c|}{ Nama Peubah } \\
\hline X31 & Luas lahan \\
\hline X32 & Jumlah dan luas ruang kelas \\
\hline X33 & Jumlah LCD \\
\hline X34 & $\begin{array}{l}\text { Jumlah dan luas ruang } \\
\text { perpustakaan }\end{array}$ \\
\hline X35 & $\begin{array}{l}\text { Jumlah buku dalam ruang } \\
\text { perpustakaan }\end{array}$ \\
\hline X36 & Jumlah dan luas ruang pimpinan \\
\hline X37 & Jumlah dan luas ruang guru \\
\hline X38 & $\begin{array}{l}\text { Jumlah dan luas ruang } \\
\text { beribadah }\end{array}$ \\
\hline X39 & Jumlah dan luas ruang UKS \\
\hline X310 & Jumlah dan luas jamban \\
\hline X311 & $\begin{array}{l}\text { Jumlah dan luas tempat } \\
\text { bermain/olahraga }\end{array}$ \\
\hline
\end{tabular}

Tabel 5. Peubah Standar Pengelolaan (X4)

\begin{tabular}{|c|l|}
\hline Kode & \multicolumn{1}{|c|}{ Nama Peubah } \\
\hline X41 & $\begin{array}{l}\text { Rencana kerja tahunan yang } \\
\text { dimiliki sekolah }\end{array}$ \\
\hline X42 & $\begin{array}{l}\text { Pedoman pengelolaan yang } \\
\text { dimiliki sekolah }\end{array}$ \\
\hline X43 & $\begin{array}{l}\text { Pihak-pihak yang terlibat } \\
\text { dalam pengambilan keputusan } \\
\text { di sekolah }\end{array}$ \\
\hline X44 & $\begin{array}{l}\text { Pihak pemangku kepentingan } \\
\text { yang dilibatkan dalam } \\
\text { pengembangan dan penetapan } \\
\text { visi, misi, dan tujuan sekolah }\end{array}$ \\
\hline
\end{tabular}

\section{Metode Analisis}

Metode analisis yang dilakukan dalam penelitian ini adalah analisis deskripsi terhadap data asal. Hal ini dilakukan untuk mengetahui gambaran data secara umum. Dalam hal ini, 4 indikator SNP sebagai variabel/peubah dan SD sebagai objek pengamatan. Analisis Deskripsi dilakukan dengan menggunakan perangkat lunak Excel.

Masing-masing standar pada penelitian ini diukur dengan batasan yang berbeda. Standar isi dan standar pengelolaan diukur dengan nilai rata-rata, kemudian standar pendidik dan tenaga kependidikan diukur dengan skor yang ditetapkan untuk setiap kualifikasi, sedangkan standar sarana dan prasarana diukur dengan luas minimum yang telah diatur dalam Peraturan Menteri Pendidikan Nasional Republik Indonesia Nomor 24 Tahun 2007 tentang Standar Sarana dan Prasarana.

\section{HASIL DAN PEMBAHASAN}

\section{Akreditasi Sekolah}

Tabel 6. Jumlah dan Persentasi Akreditasi Sekolah

\begin{tabular}{|c|c|c|}
\hline Akreditasi & $\begin{array}{c}\text { Jumlah } \\
\text { SD }\end{array}$ & $\begin{array}{c}\text { Presentasi } \\
(\mathbf{\%})\end{array}$ \\
\hline A & 9 & 30 \\
\hline B & 9 & 30 \\
\hline C & 1 & 3,33 \\
\hline $\begin{array}{c}\text { Belum } \\
\text { Terakreditasi }\end{array}$ & 11 & 36,67 \\
\hline Total & 30 & 100 \\
\hline
\end{tabular}


Dari grade akreditas terdapat $9(30 \%)$ Sekolah terakreditasi A, 9 (30\%) sekolah juga terakreditasi B dan 1 (3,33\%) sekolah terkreditasi C, sedangkan yang belum terakreditasi sebesar $36,67 \%$ atau 11 seekolah. Sekolah yang terakreditasi A adalah SD Negeri 2 Ratahan (K1), SD GMIM Ratahan (K3), SD Negeri 1 Liwutung (K6), SD Negeri 2 Liwutung (K7), SD Negeri 3 Liwutung (K8), SD Negeri 1 Mundung (K12), SD GP Kali (K15), SD Negeri 1 Tombatu (K24), dan SD Inpres Kali (K29) sedangkan yang belum terakreditasi adalah SD GMIM Kuyanga (K13), SD GMIM Lobu (K16), SD Negeri Kecil Banga (K17), SD GMIM Bunag (K18), SD Negeri Maulit (K19), SD Negeri Inpres Molompar (K20), SD GMIM Watuliney (K21), SD Negeri 1 Belang (K22), SD Negeri 1 Toundanow (K26), SD GMIM 1 Silian (K27), SD Negeri Silian Raya (K28).

\section{Analisis Deskripsi SD}

Dengan menggunakan program Microsoft Office Excel 2010. Maka diperoleh tampilan-tampilan grafik deskripsi SD masing-masing peubah seperti yang ditampilkan di bawah ini:

\section{Peubah Standar Isi (X1)}

\section{Kurikulum yang Digunakan (X11)}

Tabel 7. Jumlah dan Persentasi Kurikulum yang Digunakan

\begin{tabular}{|c|c|c|}
\hline $\begin{array}{c}\text { Kurikulum } \\
\text { yang digunakan }\end{array}$ & $\begin{array}{c}\text { Jumlah } \\
\text { SD }\end{array}$ & $\begin{array}{c}\text { Persentasi } \\
(\boldsymbol{\%})\end{array}$ \\
\hline KTSP & 13 & 43,33 \\
\hline K13 & 2 & 6,67 \\
\hline Gabungan & 15 & 50,00 \\
\hline Total & 30 & 100 \\
\hline
\end{tabular}

\section{Jenis Penilaian Yang Diterapkan Dalam Kurikulum Di Sekolah (X12)}

Jenis-jenis penilaian yang diterapkan dalam kurikulum di sekolah-sekolah yang ada di Kabupaten Minahasa Tenggara adalah ujian tertulis, ujian lisan, pengukuran sikap, penilaian hasil karya berupa tugas, dnn portofolio atau prestasi siswa. Nilai yang dilihat pada jenis-jenis peniaian ini adalah berapa persen nilai yang dipakai sekolah untuk masing-masing jenis penilaian. Nilai ini menggunakan skala 0 sampai dengan 10 dalam artian $0 \%$ sampai dengan $100 \%$.

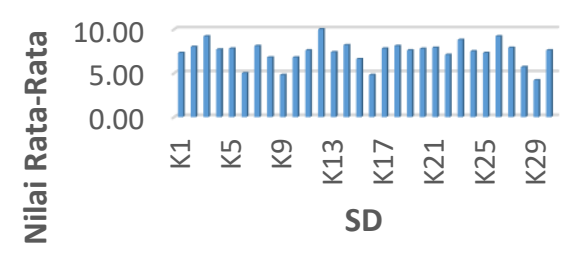

Gambar 1. Nilai rata-rata jenis penilaian yang diterapkan dalam kurikulum di sekolah

SD Negeri 1 Mundung (K12) memiliki jenis penilaian yang paling baik dibandingkan SD yang lain di Kab. Minahasa Tenggara dengan nilai rata-rata $10, \mathrm{SD}$ GMIM Ratahan (K3) dan SD Negeri 1 Toundanow (K26) menempati urutan kedua untuk jenis penilaian yang baik dengan nilai rata-rata 9,2 .

\section{Peubah Standar Pendidik dan Tenaga Kependidikan (X2)}

Pengolahan data pada peubah standar pendidik dan tenaga kependidikan pada penelitian ini menggunakan skor. Skor tersebut akan di dapatkan melalui bobot yang ditentukan untuk tiap kualifikasi pendidik dan tenaga kependidikan. Adapun bobot yang telah ditentukan untuk masing-masing kualifikasi, yaitu : 10 untuk S3, 7 untuk S2, 4 untuk D4/S1, 3 untuk D3, 2 untuk D2, 1 untuk SMA sederajat dan 0,5 untuk pendidikan di bawah SMA.

\section{Jumlah dan Kualifikasi Guru (X21)}

SD Negeri 1 Tombatu (K24) adalah yang terbaik dengan skor 63, kemudian diikuti SD Negeri 2 Liwutung dengan skor 61 . Sedangkan SD Negeri Kecil Banga (K17) berada diposisi terbawah dengan skor 12 yang artinya jumlah dan kulifikasi guru di sekolah ini masih kurang. 


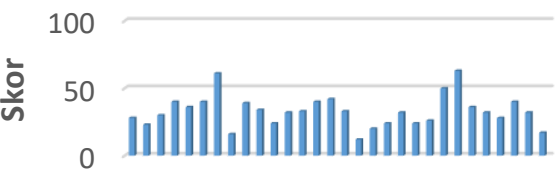

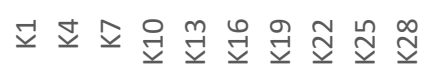

$$
\begin{aligned}
& \text { SD }
\end{aligned}
$$

Gambar 2. Jumlah dan Kualifikasi Guru (X21)

\section{Kualifikasi Kepala Sekolah (X22)}

Terlihat pada gambar bahwa ada 6 sekolah atau sebanyak 20\% memiliki kualifikasi kepala sekolah dengan pendidikan S2 dan ada 2 sekolah atau sebanyak 6,67\% memiliki kualifikasi kepala sekolah dengan pendidikan sederajat SMA. Kemudian sisanya 22 sekolah atau sebanyak 73,33\% memiliki kualifikasi kepala sekolah dengan pendidikan D4/S1.

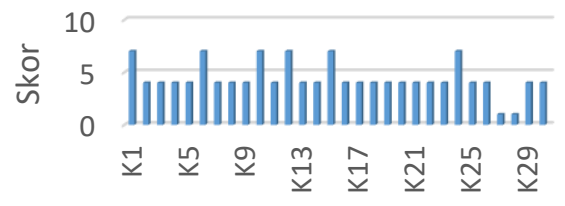

$$
\begin{aligned}
& \text { SD }
\end{aligned}
$$

Gambar 3. Kualifikasi Kepala Sekolah (X22)

\section{Jumlah dan Kualifikasi Tenaga Administrasi (X23)}

SD GMIM Ratahan (K3) memiliki kualifikasi yang cukup rendah dengan skor 1 , kemudian diatasnya ada SD Negeri Wioi (K2) dengan skor 3 dan ada 12 sekolah atau sebanyak $40 \%$ dengan kualifikasi teratas memiliki skor 4. Jumlah dan kualifikasi guru pada gambar 9 juga menunjukan bahwa ada 16 sekolah atau sebanyak 53,33\% tidak memiliki tenaga administrasi.

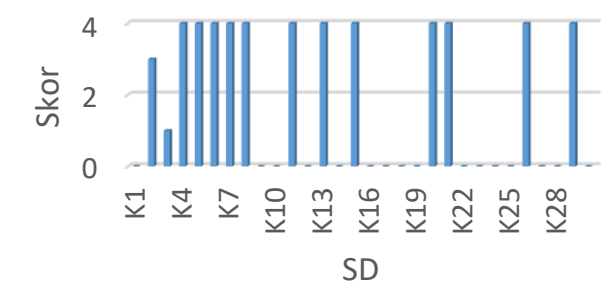

Gambar 4. Jumlah dan Kualifikasi Tenaga Administrasi (X23)

\section{Jumlah dan Kualifikasi Tenaga Perpustakaan (X24)}

SD Inpres Tosuraya (K4) memiliki jumlah dan kualifikasi tenaga perpustakaan yang lebih tinggi dibandingkan SD yang lain di Kab. Minahasa Tenggara dengan skor 8, SD Inpres Pangu (K9), SD Negeri 1 Toundanow (K26) dan SD Inpres Kali (K29) menempati urutan kedua jumlah dan kualifikasi tenaga perpustakaan dengan skor 4, kemudian SD Negeri 1 Mundung (K12), SD Negeri 1 Belang (K23), dan SD GMIM Tambelang (K30) menempati posisi ketiga dengan skor 1 . Sedangkan sisanya ada 23 sekolah atau sebanyak $76,67 \%$ tidak memiliki tenaga perpustakaan.

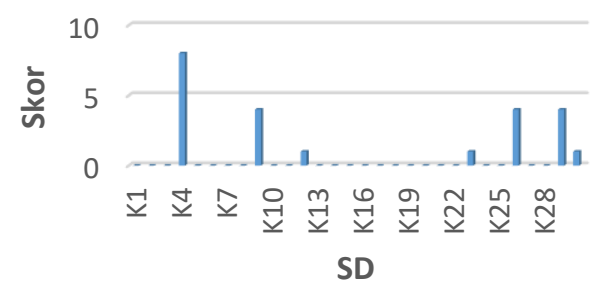

Gambar 5. Jumlah dan Kualifikasi Tenaga Perpustakaan (X24)

\section{Jumlah dan Kualifikasi Tenaga Kebersihan (X25)}

Terdapat 10 sekolah atau sebanyak 33,33\% memiliki jumlah dan kualifikasi tenaaga kebersihan yang paling tinggi dengan skor 1, di tempat kedua ada SD Negeri 1 Mundung (K12) dan SD Negeri Silian Raya (K28) dengan skor 0,5, kemudian sisanya terdapat 18 sekolah atau sebanyak $60 \%$ tidak memiliki tenaga kebersihan.

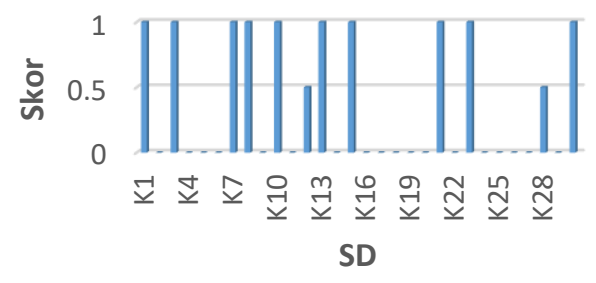

Gambar 6. Jumlah dan Kualifikasi Tenaga Kebersihan 


\section{Peubah Standar Sarana dan Prasarana (X3)}

\section{Luas Lahan (X31)}

Terdapat 13 sekolah yang memiliki luas lahan di bawah standar minimum yang telah ditetapkan yakni $1340 \mathrm{~m}^{2}$, sekolahsekolah tersebut adalah SD GMIM Ratahan (K3), SD Inpres Tosuraya (K4), SD GMIM Rasi (K5), SD Negeri 2 Liwutung (K7), SD Negeri 1 Molompar (K11), SD GP Kali (K15), SD GMIM Lobu (K16), SD Negeri 1 Belang (K23), SD Negeri 1 Toundanow (K26), SD GMIM 1 Silian (K27), SD Negeri Silian Raya (K28), SD Inpres Kali (K29), dan SD GMIM tambelang (K30). Sedangkan sekolah yang memiliki luas terbesar adalah SD Negeri Kecil Banga dengan luas lahan $10.200 \mathrm{~m}^{2}$

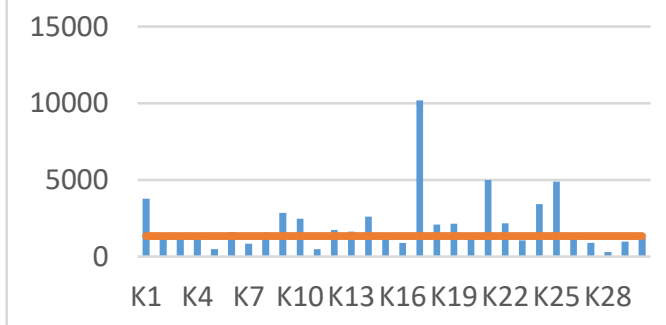

Gambar 7. Luas lahan sekolah

\section{Luas Ruang Kelas (X32)}

Sekolah yang memiliki nilai tertingggi untuk jumlah dan luas ruang kelas adalah SD Negeri 2 Tombatu (K14) dan SD Negeri 1 Tombatu (K24) dengan luas keseluruhan $448 \mathrm{~m}^{2}$. Sedangkan sekolah yang memiliki niai terbawah adalah SD Negeri Wioi (K2) dan SD Negeri Kecil Banga (K17) dengan luas masing-masing $150 \mathrm{~m}^{2}$ dan 168 $\mathrm{m}^{2}$ dikarenakan jumlah dan luas ruang kelas yang tidak sesuai dengan standar minimum yang telah ditetapkan dalam standar sarana dan prasarana yaitu $180 \mathrm{~m}^{2}$.

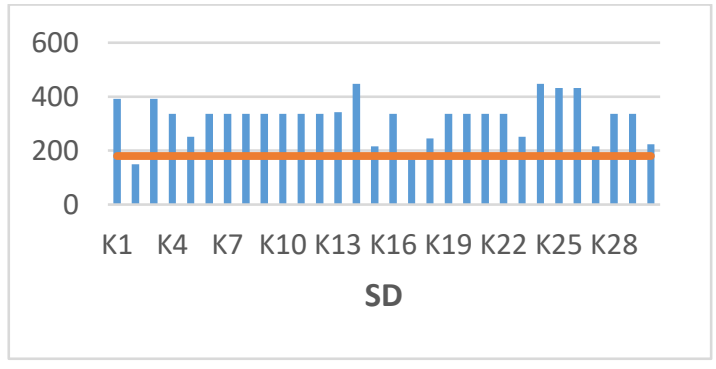

Gambar 8. Luas Ruang Kelas

\section{Jumlah LCD (X33)}

Jumlah LCD terbanyak adalah SD Negeri 3 Liwutung (K8) dengan jumlah 3 LCD, diurutan kedua ada SD Negeri 2 Ratahan (K1), SD GMIM Rasi (K5), SD Negeri 1 Liwutung (K6), SD Negeri 2 Liwutung (K7), SD Negeri 1 Mundung (K12), SD GMIM Kuyanga (K13) dan SD Negeri Silian Raya (K28) dengan jumlah 2 LCD, kemudian diurutan ketiga ada SD Inpres Tosuraya (K4), SD Negeri 2 Tombatu (K14), SD GMIM Ranoketang (K25) dan SD Inpres Kali (K29) dengan jumlah 1 LCD dan sisanya sebanyak 18 sekolah tidak memiliki LCD.

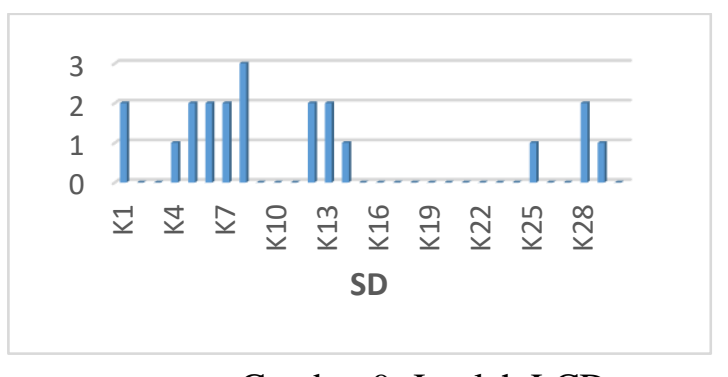

Gambar 9. Jumlah LCD

\section{Luas Ruang Perpustakaan (X34)}

Terdapat 3 sekolah yang memiliki nilai terbawah dan tidak memenuhi standar yang ditetapkan untuk luas ruang perpustakaan dikarenakan sekolah-sekolah tersebut tidak memiiki ruang perpustakaan. Sekolah-sekolah yang dimaksud adalah SD Negeri Kecil Banga (K17), SD GMIM Watuliney (K21) dan SD Negeri Silian Raya (K28). Sekolah dengan nilai tertinggi untuk jumlah dan ruang perpustakaan adalah SD GMIM Ranoketang (K25) dan SD Negeri 1 Toundanow (K26) dengan luas $72 \mathrm{~m}^{2}$.

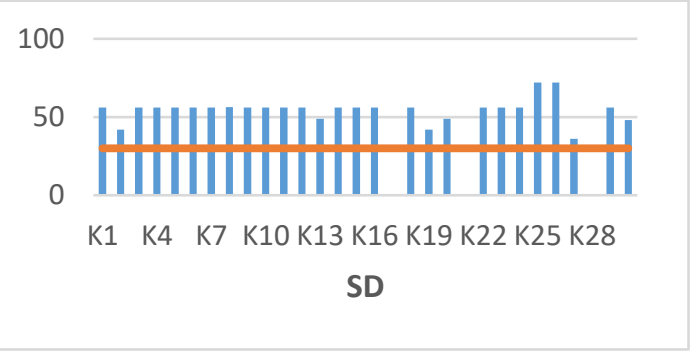

Gambar 9. Luas Ruang Perpustakaan

\section{Jumlah Buku di Perpustakaan (X35)}

Jumlah buku di perpustakaan terbanyak adalah SD GMIM Wioi (K2), SD Inpres Tosuraya (K4), SD Negeri 1 Liwutung (K6) dan SD GMIM Ranoketang (K25) 
dengan jumlah buku 4000. Sedangkan pada SD Negeri Kecil Banga (K17), SD GMIM Watuliney (K21) dan SD Negeri Silian Raya (K28) tidak memiliki buku karena tidak memiliki perpustakaan.

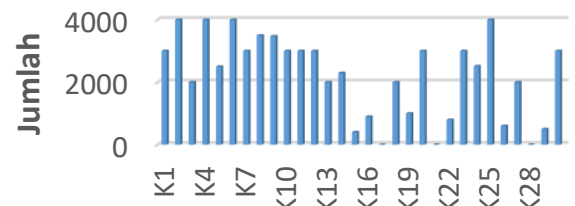

$$
\begin{aligned}
& \text { SD }
\end{aligned}
$$

Gambar 10. Jumlah Buku di Perpustakaan

\section{Luas Ruang Pimpinan (X36)}

Terdapat 10 sekolah yakni SD Inpres Pangu (K9), SD Negeri 2 Tombatu (K14), SD GP Kali (K15), SD Negeri Kecil Banga (K17), SD GMIM Bunag (K18), SD Negeri Maulit (K19), SD Negeri 1 Toundanow (K26), SD GMIM 1 Silian (K27), SD Negeri Silian Raya (K28) dan SD GMIM Tambelang (K30) yang tidak memiliki ruang pimpinan. Sekolah yang memiliki nilai tertinggi untuk jumlah dan luas ruang pimpinan adalah SD GMIM Watuliney (K21) dan SD GMIM Ranoketang (K25) dengan luas $72 \mathrm{~m}^{2}$. Sedangkan SD Negeri Wioi (K2) memiliki luas $9 \mathrm{~m}^{2}$, tidak memenuhi standar yang ditetapkan yaitu $12 \mathrm{~m}^{2}$.

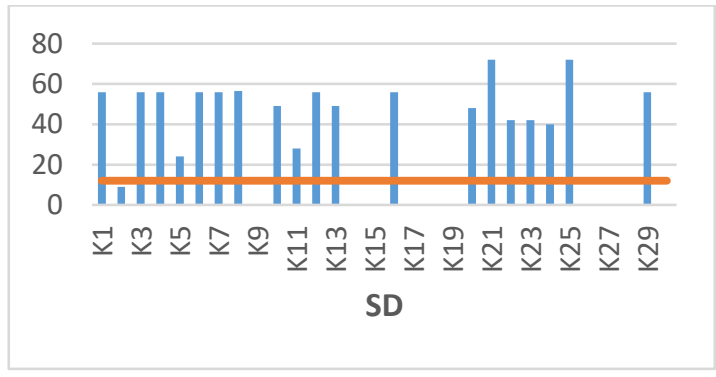

Gambar 11. Luas Ruang Pimpinan

\section{Luas Ruang Guru (X37)}

Terdapat 4 sekolah yang nilainya dibawah $32 \mathrm{~m}^{2}$ yaitu SD Negeri Wioi (K2) dengan luas $25 \mathrm{~m}^{2}$, SD GMIM 1 Silian (K27) dengan luas $24 \mathrm{~m}^{2}$, SD Negeri Silian Raya (K28) dengan luas 10,5 $\mathrm{m}^{2}$ dan SD GMIM Tambelang (K30) dengan nilai luas $30 \mathrm{~m}^{2}$ dan terdapat 5 sekolah yang tidak memiliki ruang guru yaitu SD Negeri 3 Liwutung (K8), SD GMIM Watuliney (K21), SD Negeri 1 Belang (K23), SD Negeri 1 Toundanow
(K26) dan SD Inpres Kali (K29). Sedangkan untuk nilai tertinggi jumlah dan luas ruang guru adalah SD Negeri 2 Liwutung (K7) dan SD GMIM Ranoketang (K25) dengan luas 72 $\mathrm{m}^{2}$.

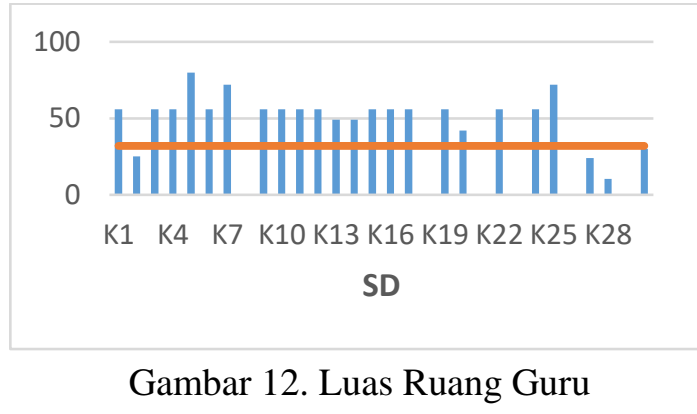

\section{Luas Ruang Ibadah (X38)}

Hanya 1 diantara 30 sekolah yang memiliki ruang ibadah khusus yaitu SD Negeri Wioi (K2) dengan luas 36. Sedangkan sekolah-sekolah lain tidak memiliki ruang ibadah khusus dan hanya menggunakan ruang kelas untuk tempat beribadah.

\section{Luas Ruang UKS (X39)}

Nilai tertinggi untuk jumlah dan luas ruang UKS dimiliki SD Inpres Liwutung (K10) dengan luas $56 \mathrm{~m}^{2}$, kemudian SD GMIM Kuyanga (K13) diurutan kedua dengan luas $49 \mathrm{~m}^{2}$ dan SD GMIM Ranoketang (K25) diurutan ketiga dengan luas $48 \mathrm{~m}^{2}$. Terdapat 5 sekolah yang luasnya dibawah $12 \mathrm{~m}^{2}$ atau tidak memenuhi standar minimum yaitu SD Inpres Tosuraya (K4) dengan luas 11,38 $\mathrm{m}^{2}$, SD GMIM Bunag (K18) dengan luas $9 \mathrm{~m}^{2}$ dan SD Negeri 2 Ratahan, SD Negeri 1 Mundung (K15) dan SD Negeri Tababo dengan luas $6 \mathrm{~m}^{2}$, dan terdapat 18 sekolah yang tidak memiliki ruang UKS.

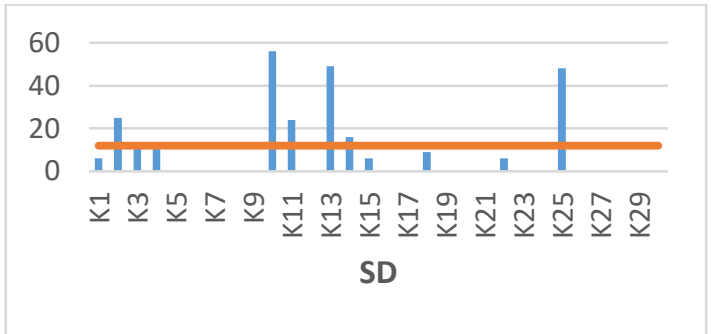

Gambar 13. Luas Ruang UKS 


\section{Luas Jamban (310)}

SD Negeri 1 Liwutung (K6) memiliki jumlah luas terbesar yaitu $48 \mathrm{~m}^{2}$ dan selanjutnya SD Negeri 1 Tombatu di urutan kedua dengan jumlah luas $40 \mathrm{~m}^{2}$. Sedangkan luas terkecil adalah SD GP Kali (K15), SD Kecil Banga (K17) dan SD Negeri Silian Raya (K28) dengan luas $6 \mathrm{~m}^{2}$.

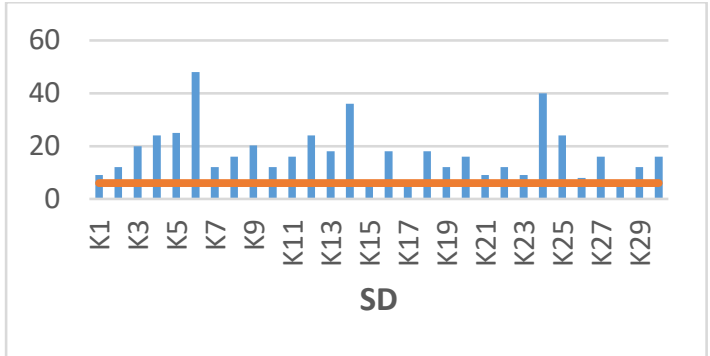

Gambar 14. Luas Jamban

\section{Luas Tempat Olahraga (X311)}

Terdapat 9 sekolah yang luas tempat olahraganya sudah memenuhi standar minimum yaitu SD Negeri 2 Ratahan (K1), SD Inpres Liwutung (K10), SD Negeri 1 Liwutung (K12), SD Negeri Kecil Banga (K17), SD GMIM Bunag (K18), SD Negeri Tababo (K22), SD Negeri 1 Belang (K23), SD Negeri 1 Tombatu (K24) dan SD GMIM Ranoketang (K25), dan yang memiliki nilai tertinggi yaitu SD GMIM Bunag (K18) dengan luas $5000 \mathrm{~m}^{2}$.

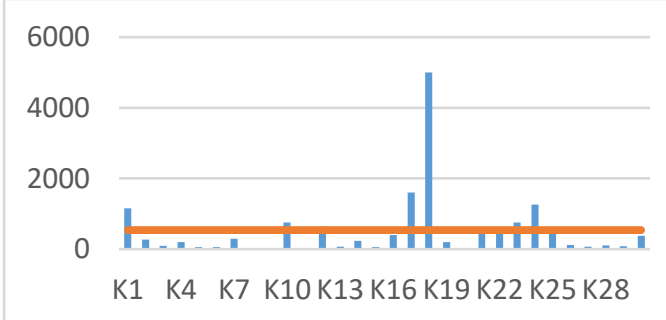

Gambar 15. Luas tempat olahraga

\section{Rencana Kerja Yang Dimiliki Sekolah (X41)}

Rencana kerja tahunan sekolah yang memiliki nilai paling tinggi yaitu SD Negeri 1 Belang dengan nilai rata-rata 10 , diikuti SD GMIM Ratahan dengan nilai rata-rata 9,83, SD Inpres Tosuraya dengan nilai rata-rata 9,17, SD Negeri 1 Belang dengan nilai ratarata 8,67, dan SD GMIM Lobu (K16) dengan nilai rata-rata 4,3 berada diurutan terbawah untuk rencana kerja yang dimiliki sekolah.

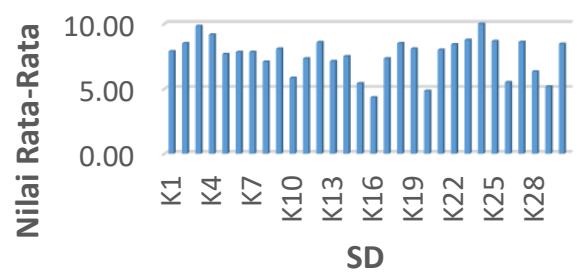

Gambar 16. Nilai rata-rata rencana kerja yang dimiliki sekolah

Pedoman Pengelolaan Yang Dimiliki Sekolah (X42)

SD N Inpres Molompar (K20) memiliki nilai paling bawah untuk pedoman pengelolaan sekolah dengan nilai rata-rata 5,63, sementara SD GMIM Ratahan (K3), SD Negeri 1 Mundung (K12), SD GP Kali (K15), SD GMIM Watuliney (K21), SD Negeri 1 Tombatu (K24), dan SD Inpres Kali(K29) memiliki nilai paling tinggi dengan nilai ratarata 10.

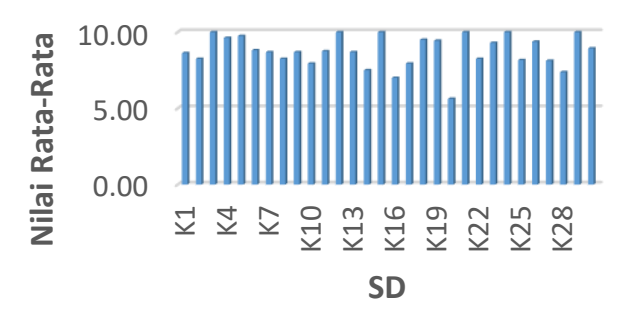

Gambar 17. Nilai rata-rata pedoman pengelolaan yang dimiliki sekolah

Pihak - Pihak Yang Terlibat Dalam Pengambilan Keputusan Disekolah (X43)

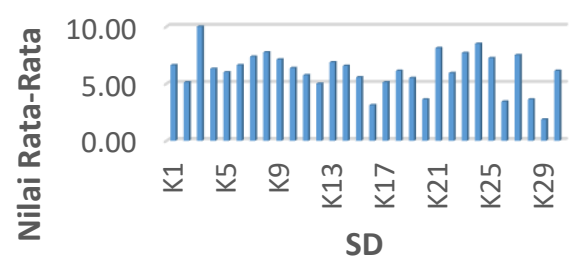

Gambar 18. Nilai rata-rata pihak-pihak yang terlibat dalam pengambilan keputusan di sekolah

Dalam pengambilan keputusan untuk sekolah SD GMIM Ratahan (K3) dapat dikatakan sangat baik dengan nilai rata-rata 10. Berbeda dengan SD GMIM Lobu yang memiliki nilai rata-rata sangat rendah yaitu 3,13. Sementara SD GMIM Watuliney (K21) 
dan SD Negeri 1 Toundanow (K26) untuk keterlibatan pihak-pihak dapat dikatakan cukup baik karena memiliki nilai rata-rata 8,13 dan 8,50 dalam hal melibatkan pihakpihak dalam mengambil keputusan disekolah.

\section{Pihak Pemangku Kepentingan Yang Dilibatkan Dalam Pengembangan Dan Penetapan Visi, Misi, Dan Tujuan Sekolah (X44)}

Keterlibatan dari pihak-pihak sebagai
pemangku kepentingan dalam
mengembangkan dan menetapkan visi, misi,
dan tujuan sekolah sangatlah penting. Akan
sangat baik sekali jika semua pihak
pemangku kepentingan terlibat didalamnya.

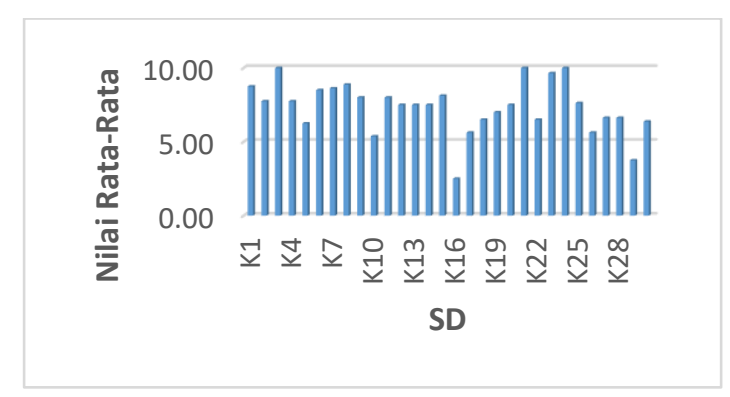

Gambar 19. Nilai rata-rata pihak pemangku kepentingan yang dilibatkan dalam pengembangan dan penetapan visi, misi, dan tujuan sekolah

Pada gambar diatas, dapat dilihat nilai rata-rata yang paling tinggi adalah SD GMIM Ratahan (K3), SD GMIM Watuliney (K21), dan SD Negeri 1 Tombatu (K24) dengan perolehan nilai 10. Selanjutnya, untuk sekolah yang berada pada kondisi kurang baik yaitu SD GMIM Lobu (K16) dengan nilai rata-rata 2,50 dan SD Inpres Kali (K29) dengan nilai rata-rata 3,75 .

\section{KESIMPULAN DAN SARAN}

\section{Kesimpulan}

Sebagian besar sekolah yang terakreditasi A sudah cukup baik dalam keempat standar yang diteliti dan memenuhi setiap standar yang ditetapkan. Namun ada $11,11 \%$ sekolah yang terakreditasi A masih kurang baik dalam beberapa standar.

Pada keempat standar yang diteliti, rata-rata nilai tertinggi dimiliki oleh sekolahsekolah yang terakreditasi A seperti SD GMIM Ratahan untuk standar isi dan standar pengelolaan, SD Negeri 2 Liwutung dan SD Negeri 1 Tombatu untuk standar pendidik dan tenaga kependidikan, sedangkan nilai tertinggi untuk standar sarana dan prasarana dimiliki oleh SD GMIM Bunag yang sekolahnya belum terakreditasi. Untuk nilai terendah pada standar pendidik dan tenaga kependidikan, standar sarana dan prasarana, dan standar pengelolaan dimiliki oleh sekolah-sekolah yang belum terakreditasi yaitu SD Negeri Kecil Banga, SD GMIM 1 Silian, dan SD GMIM Lobu. Sedangkan nilai terendah pada standar isi dimiliki oleh SD Negeri 1 Liwutung yang merupakan salah satu sekolah yang sudah terkreditasi A.

\section{Saran}

Dari ke empat standar nasional pendidikan yang digunakan, ada beberapa kekurangan dari masing-masing sekolah yang perlu diperhatikan di setiap sekolah, terutama pada standar sarana dan prasarana sekolah yang masih jauh dari cukup diantaranya ruang kelas dan ruang kerja kepala sekolah serta guru.

Selain itu juga perlu diperhatikan sekolah-sekolah yang telah terakreditasi baik namun belum memenuhi standar yang ditetapkan dan sekolah-sekolah yang belum terakreditasi agar bisa memenuhi standarstandar yang telah ditetapkan.

\section{DAFTAR PUSTAKA}

Agust, J. 2016. MITRA, Kabupaten Minahasa Tenggara, Sulawesi Utara. Http://www.skyscrapercity.com/sho wthread.php?t=1911547 [6 Desember 2017]

Daman, R. dan D. Hatidja. 2012. Pemetaan SMP-SMP di Kab. Minahasa Tenggara Berdasarkan Standar Pendidikan dan Tenaga Kependidikan, Standar Sarana dan Prasarana, Standar Pengelolaan, dan Standar Pebiayaan Menggunakan Analisis Biplot. Jurnal De Cartesian 1(1).

Johnson, R. A and D. Wichern. 2005. Applied Multivariate Statistical Analysis. Fifth Edition. Prentice Hall Inc., USA. 
Hatidja, D. 2010. Analisis Biplot Terhadap Mutu Pendidikan SMA-SMA di Kota Manado. Jurnal Ilmiah Sains, 10(1).

Hatidja, D. dan R. Take. 2012. Pemetaan SMP-SMP di Kab. Minahasa Tenggara Berdasarkan Standar Kompetensi Lulusan, Standar Isi dan Standar Proses. Prosiding Seminar Nasional Matematika XVI, Bandung 3-6 Juli 2012.

Peraturan Pemerintah Republik Indonesia Nomor 19 Tahun 2005 tentang Standar Nasional Pendidikan.

Purwanto, Ch., D. Hatidja dan M. Paendong. 2015. Pemetaan SMA/SMK Di Kabupaten Minahasa Tenggara Berdasarkan Empat Indikator Standar Nasional Pendidikan Dengan Menggunakan Analisis Biplot. Jurnal De Cartesian 4(1).

Rembang, P., D. Hatidja, dan H. Komalig. 2017. Deskripsi SMA/SMK Di Kabupaten Minahasa Tenggara Berdasarkan Indikator Standar Nasional Pendidikan Berbasis Evaluasi Diri Sekolah (Standar Sarana Dan Prasarana, Standar Pengelolaan, Standar Pembiayaan Pendidikan Dan Standar Penilaian Pendidikan). Jurnal Ilmiah Sains 17(2).

Ridwan dan Akdon. 2005. Rumus dan Data dalam Aplikasi Statistika. Alfabeta.

Sepang, M.Z., D. Hatidja, dan Y. Langi. 2015. Pemetaan SMA dan SMK Berdasarkan Standar Kompetensi Lulusan, Proses, Pembiayaan Pendidikan, dan Penilaian Pendidikan Menggunakan Analisis Biplot di Kabupaten Minahasa Tenggara. Jurnal De Cartesian 4(1).

Simamora, B. 2005. Analisis Multivariat Pemasaran. PT Gramedia Pustaka Utama, Jakarta.
Tarega, S.K., D. Hatidja, dan M. Paendong. 2017. Deskripsi SMA/SMK Di Kabupaten Minahasa Tenggara Berdasarkan Indikator Standar Nasional Pendidikan Berbasis Evaluasi Diri Sekolah (Standar Kompetensi Lulusan, Standar Isi, Standar Proses, Standar Pendidik dan Tenaga Kependidikan). Jurnal Ilmiah Sains 16(2).

Taogan, Y.A., M. Paendong, dan C. Mongi. 2016. Analisis Biplot terhadap Pemetaan SMA di Kabupaten Minahasa Selatan berdasarkan Standar Isi, Standar Pendidik dan Tenaga Kependidikan, Standar Kompetensi Lulusan dan Standar Penilaian Pendidikan. Jurnal De Cartesian 5(1).

Undang-Undang Republik Indonesia Nomor 20 Tahun 2003 Tentang Sistem Pendidikan Nasional. 